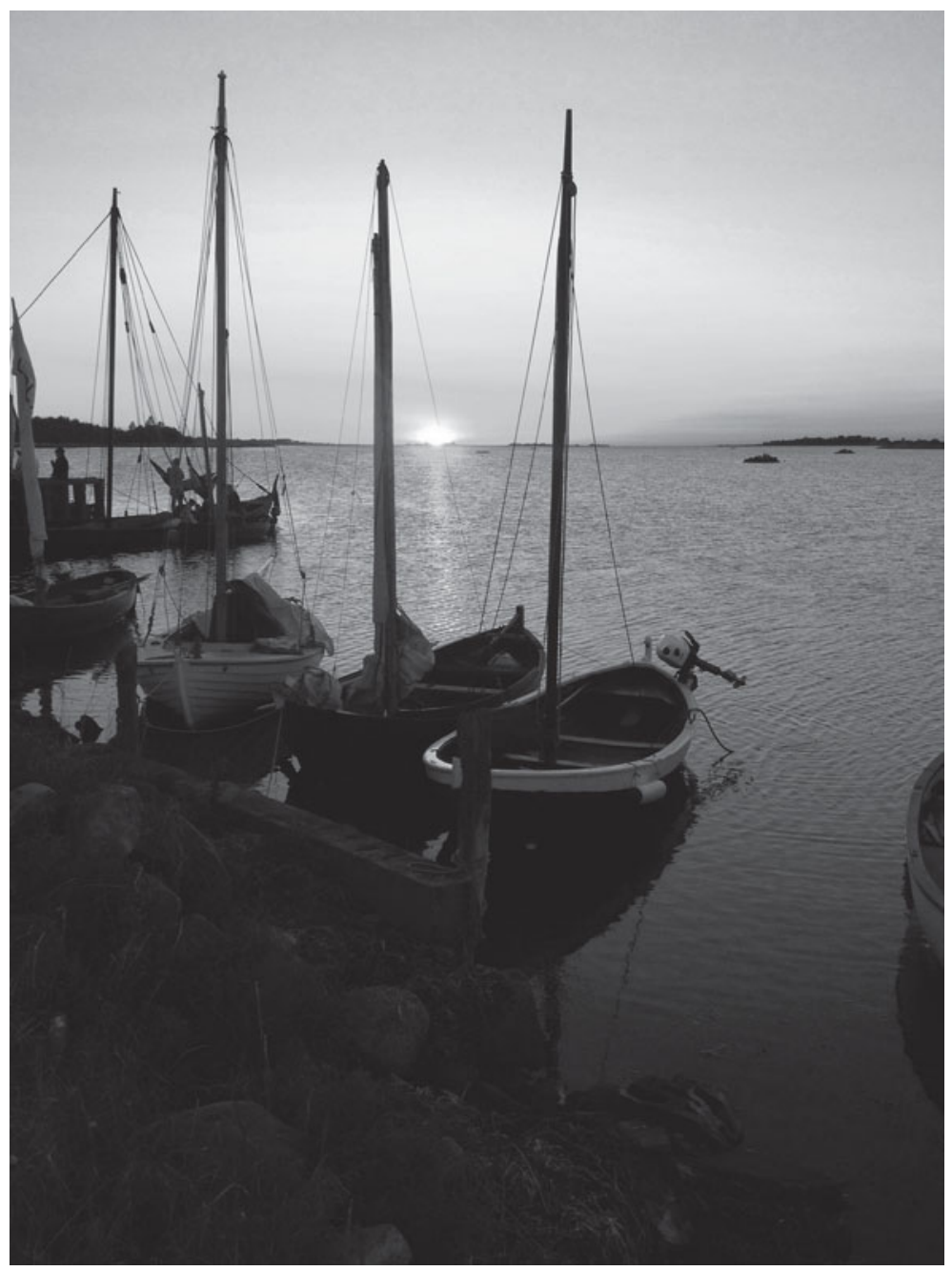

\title{
Ekspeditionen som undersøgelsesmetode
}


Knud Rasmussen, Ludvig Mylius Eriksen, Thor Heyerdahl og Fritjof Nansen var ledere af videnskabelige ekspeditioner i det forrige århundrede. Deres opdagelser har fået stor betydning for både samtid og eftertid. Deres bedrifter har været med til at bringe videnskaben ud af elfenbenstårnet, og deres eventyr har på mange måder været til stor inspiration for en bred skare. Ekspeditionerne gik typisk til fjerne himmelstrøg, og bestræbelserne var ofte at afdække "hvide" pletter på landkortet. De havde lyst til at opdage og forstå det, man ikke kan læse sig til. Deres oplevelser, deres undren, deres møder med andre kulturer, deres videnskabelige perspektiver og deres arbejdsmetoder har inspireret mig til at spørge, hvorvidt og hvordan man kan anvende nogle af de samme metoder og tage på ekspedition i sin egen kultur.

I forbindelse med mit Ph.d.-projekt ønskede jeg at undersøge begrænsninger og muligheder for turfriluftsliv i Danmark. Turfriluftslivet udøves i et landskab, hvor der også er andre friluftsaktører og landskabsinteressenter. Jeg var derfor interesseret $i$, hvordan der $i$ forskellige friluftskulturer bliver udøvet friluftsliv. Jeg ville vide, om der udspiller sig en kamp om retten til at udøve friluftsliv mellem forskellige brugere af naturen, og jeg ville gerne finde ud af, hvordan den i så fald manifesterede sig? Derfor måtte jeg tæt på friluftslivsudøverne, lodsejerne og de andre friluftsinteressenter. Jeg var interesseret $\mathrm{i}$ at få kendskab til deres måde at handle, kommunikere og tænke på.

Jeg sejlede derfor, med det formål at indhente viden om forskellige friluftskulturer i perioden 2009-2014, ud på en del flerdagesture i Helnæsbugten på Sydvestfyn. Jeg oplevede i mødet med fritidsfiskerne på Nabben, sejlerne ved marinaen i Faldsled og menneskene på campingpladserne, at når jeg skulle hente viden om dis- se brugere og deres kulturer, så var der de samme erkendelsesmønstre i spil, som jeg kendte fra friluftslivet og vejledningspædagogikken.

Jeg har igennem mange år via mit virke på Helnæs Mølle Friluftsgaard og Syddansk Universitet gode erfaringer med at arbejde med friluftsliv som redskab til at nå forskellige faglige og pædagogiske mål. Eksempelvis har jeg formidlet den fynske kystkultur igennem det at tage studerende på ture i traditionelle smakkejoller. Ved at ro og sejle jollerne i deres landskab, ved at fiske som de gamle kystbønder gjorde og ved at anvende den samme maritime termologi og sejl- og fiskeritualer, er der opnået kulturel indsigt, vi ikke kunne have erhvervet via historiebøgerne.

Vejledningspædagogikken har rødder i den norske friluftstradition, norske bygdetraditioner, ungdomsoprøret og erfaringspædagogikken (Breivik, 1991). Efter anden verdenskrig steg interessen for formelle kurser i friluftsliv, og kursusdeltagere strømmede til bræ-kurser, klippeklatrekurser, kurser i sejlads og lignende. Der var et stort vidensbehov, og kyndige instruktører kunne øse af deres kundskab. Men kursusmagerne opdagede, at der var forskel på teoretisk viden og praktisk kunnen. Oplæring i bestemte teknikker hjalp nødvendigvis ikke mennesker til at tackle de mangfoldige forskellige situationer, som de mødte i naturen. Der opstod et behov for kurser, der var udformet anderledes. De oplevede ligeledes, at det af og til kunne knibe med motivationen hos kursusdeltagerne. Det kunne være vanskeligt at forklare kursusindholdets relevans. Der var en erkendelse af, at man ikke kunne skelne mellem læringens form og dens indhold. Man mente, at naturen, sådan som den opførte sig i forskellige situationer, måtte blive den virkelige læremester. Derfor opstod et behov for at udvikle en 
pædagogisk metode, hvor deltagerne lærte af egne erfaringer og oplevede glæde ved at færdes i naturen (Tordsson, 2006). Metoden blev i 60'erne og 70'erne udviklet af Nils Faarlund og andre friluftsvejledere (Sookermany \& Eriksen, 2007) og ved Trantjern seminaret i 1979 blev den i dokumentet "Krav til vejledere i friluftsliv" gjort til norm for vejledning i friluftsliv (For-Ut, 1979). Vejledningspædagogikken og den tilknyttede metode er med stor succes blevet benyttet i mange år. Det et således grundlæggende de samme vejledningsprincipper fra Trantjern, der anvendes på friluftslivsstudiet $i$ Bø i 1991 (Telemark Distrikthøgskole, 1991), som Atle Tellnæs skriver om i 1994 (Tellnes, 1994) og som Tordsson benytter i "Perspektiver på friluftslivets pædagogik" (Tordsson, 2006). Det er ligeledes i store træk den samme pædagogiske metode, friluftsuddannelserne, universiteterne, mange højskoler og efterskoler i Danmark i dag benytter.

Disse oplevede ligheder mellem disse ekspeditioner og friluftslivspædagogikken har sammen med min generelle interesse for ekspeditioner og behovet for at forstå forskellige friluftskulturer inspireret mig til at se nærmere på ekspeditionen som undersøgelsesmetode.

Spørgsmålene, der i denne artikel forfølges er:

a) Hvad er det særlige ved ekspeditionen som metode?

b) Hvilke erkendelsesprocesser er der i spil?

c) Hvordan kan den anvendes i praksis?

Ekspeditioner og ture i kajak, kano og i traditionelle smakkejoller i Helnæsbugten og det Sydfynske øhav udgør sammen med ekspeditionslitteratur den empiriske ballast for at udvikle "Ekspeditionen som undersøgelsesmetode". Jeg har været af sted alene, med studerende og med

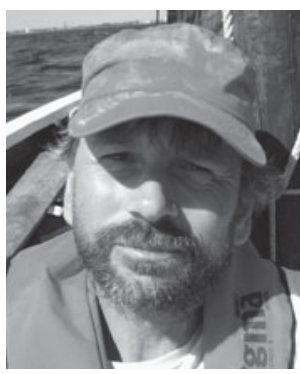

forskningskollegaer fra Danmark og udlandet, på små og større ekspeditioner i Helnæsbugten og i det sydfynske øhav.

Jeg har sammen med forskningsgruppen "Rum og bevægelse" på Institut for Idræt og Biomekanik på Syddansk Universitet været på en mindre ekspedition i Helnæsbugten, hvor der blev sat særlig fokus på metoden. Empiri, samtaler og diskussioner fra disse ekspeditioner har bidraget til at forstå og teste ekspeditionsmetoden. Efterfølgende har denne gruppe og siden kollegaer fra Aarhus Universitet været med til at reflektere over metoden og dens praktiske anvendelsesmuligheder.

Jeg har i mine undersøgelser anvendt friluftslivet som ramme for mine ekspeditioner.

\section{EKSPEDITION OG VEJLEDNING I FRILUFTSLIV}

Ekspeditionen og ekspeditionen som metode er ikke nyere dato. Carsten Niebuhr tog på den store arabiske ekspedition i 1761-67, og Kaptajn Thomas Jepsen Sødring var på den første danske sydhavsekspedition i 1839 (Holbech, 1841). Det er heller ikke nyt at tage på ekspedition i egen kultur, således viste Achton Friis, da han rejste rundt på øerne, der siden blev til værket "De Danskes øer", at man sagtens kan foretage en ekspedition i sit eget land. Siden har bl.a. Jørgen Flindt Pedersen og Erland Porsmose med skibet Rylen taget på videnskabelige rejser i det Sydfynske øhav (Pedersen, 2011). På 
trods af ekspeditionens mange år på bagen, så er der ikke i ekspeditionslitteraturen noget litteratur, der for alvor udfolder ekspeditionens metodiske egenskaber og som giver indsigt $\mathrm{i}$ dens erkendelseskvaliteter og konkrete virkemidler.

Vejledningspædagogikken, der udgør en vigtig gren af friluftspædagogikken, kan imidlertid hjælpe på os på vej til dybere forståelse for ekspeditionen som metode. Den kan give indsigt til at forstå, hvorfor og hvordan vi via ekspeditionen kan indsamle empiri, der ikke kan erhverves ad anden vej. Vejledningspædagogikken bygger på en antagelse af, at der igennem friluftsudøvelse, udfordringer og ophold i naturen etableres et erkendelsesrum, der baner vej for integreret læring og forskellige former for erkendelse (Tordsson, 2006). I vejledningspædagogikken er sanserne central for læring og indsigt, og denne vej til erkendelse er lige så betydningsfuld som den abstrakte tænkning.

På samme måde forholder det sig på en ekspedition. Her arbejder forskeren med en række menneskelige, integrerede erkendelsesveje. Der sanses, der skelnes, der anes. Han eller hun tager imod, føler på kroppen, lever sig ind i, forstår, fortolker, sættes på prøve og udlever og erfarer i konkret handling.

\section{EKSPEDITIONEN OG METODEN}

Smakkejollen fyldes med proviant, telt, førstehjælpsudstyr, kort og dagbøger. Sejlene sættes og jollen stævner ud. Den lille ekspeditionsgruppe tager på ekspedition i Helnæsbugten med det formål at undersøge friluftlivsudøvelsen ved bugtens campingpladser på marinaen Faldsled på fiskelejet ved Nabben og hos kitesurferne ved Langøre inderst i bugten.

Hvad kendetegner en ekspedition ind i egen kultur? Og hvordan erkendes der?
I følge den danske ordbog er en ekspedition: "en laengere rejse til et uudforsket område, f.eks. med videnskabeligt eller militoert formål” (Gyldendal, 2015). Det centrale i definitionen er, at man er på tur over længere tid, og at der undersøges noget, der er uudforsket. På ovennævnte ekspedition varede rejsen fire dage, og den havde til hensigt at udforske friluftskulturer i Helnæsbugten.

En ekspedition har et mål, der systematisk forfølges, og derfor er de fleste ekspeditioner bygget op omkring følgende fem faser:

1) Målsætning

2) Planlægning

3) Ekspedition

4) Databearbejdning og analyse

5) Formidling

På en ekspedition tages afsæt i en undren. Ekspeditionslederen og evt. ekspeditionsholdet undrer sig over noget, de gerne vil undersøge nærmere. Disse overvejelser udløser spørgsmål, og der skabes på baggrund af litteratursøgning en problemformulering og eventuelt en hypotese. På denne baggrund undersøges, hvilken teori og metode, der skal anvendes, hvorefter der udarbejdes et undersøgelsesdesign. De metodeværktøjer og det teoriapparat, der anvendes, er bestemt af det eller de spørgsmål, forskeren vil undersøge. Så langt ligner en ekspedition en hvilken som helst anden akademisk undersøgelse. På samme måde minder planlægning, databearbejdning, analyse og formidling også om andre projekter, hvorfor der ikke dvæles mere ved disse punkter her. Det er selve rejsen - ekspeditionen - der er dens særkende. På denne finder et kulturmøde sted, der erkendes på flere planer og der indhentes empiri.

For at kulturmødet og forskellige former for erkendelse kan finde sted, skal der også være 
nogle grundlæggende rammer på plads. Disse rammer udgør selve rejsen (ekspeditionen), som foregår over tid, i et landskab og som regel fra et givet fartøj. Bevægelsen, gruppen og det enkle liv, der leves undervejs, er også vigtigt for en ekspedition.

Ekspeditionen som metode er en empirisk metode, der anvendes til kulturanalyse og som har til formål at skabe ny erkendelse. Ved at være af sted på en ekspedition i længere tid (f.eks. i en kano, kajak, sejlbåd eller til fods) og ved at være i landskabet og tæt på det der forskes i, skabes et kulturmøde, der giver ekspeditionsgruppen mulighed for opmærksomhed, refleksion og diskussion. Derved bliver det muligt for forskeren eller forskerholdet at komme tæt på en given problemstilling, anskue den fra forskellige perspektiver, og ad den vej tilegne sig ny viden.

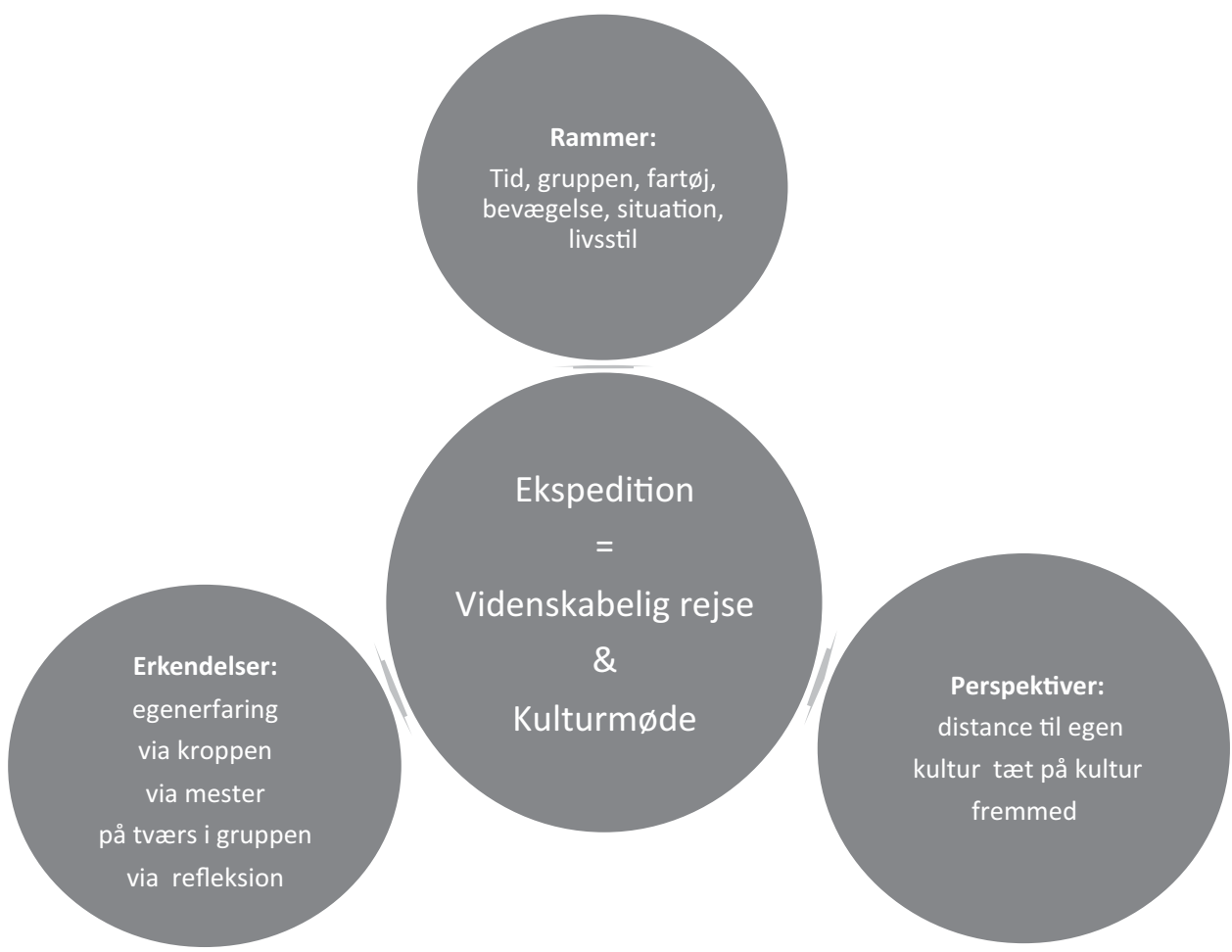

Model 1: En ekspedition er en videnskabelig rejse, hvor der etableres et kulturmøde. De grundlæggende forhold ved en ekspedition omhandler rammerne, perspektiverne og forskellige erkendelsesformer. Rammerne udgør forudsætningen for at ekspeditionen og kulturmødet kan finde sted. De tre forskellige perspektiver etableres som en konsekvens af ekspeditionen og kulturmødet. Forskellige former for erkendelse opstår som følge af kulturmødet, ekspeditionen, rammerne og de anlagte perspektiver. 


\section{KULTURMøDET OG FORSKELLIGE PERSPEKTIVER}

Kulturmødet danner rammer om en række måder at indhente viden på, og gør desuden forskeren eller forskerholder i stand til:

1) at distancere sig fra sin egen kultur.

2) at komme tæt på den kultur, der undersøges

3) at gøre sig fremmed over for den kultur, der undersøges.

\section{Distance til egen kultur}

Fritjoff Nansen (1861-1930) kan hjælpe os til at forstå betydningen af at få sig egen kultur på afstand. I en tale til den norske ungdom siger den norske diplomat, opdagelsesrejsende og videnskabsmand:

La os tænke os et væsen utenfor vor klode som sitter og ser ned paa os i en kikkert. Hvad faar han se? Nogen smaa dyr, som lever paa overflaten av denne kloden, og som for en stor del har klumpet sig sammen i nogen kasser, som staar i rækker og rad paa forskjellige steder. I disse kassene lever de mesteparten av døgnet. Saa smetter de ut av en, piler avsted langs de trange mellemrummene mellem kassene for saa at smette ind $i$ en ny. Det er de en stund, saa ut og saa tilbake til den første igjen. Og inde i disse kassene og i rummene mellem dem tilbringer de omtrent hele sit liv (Nansen, 1942, s. 578).

\section{Og han fortsætter:}

Naar nu disse kassemenneskene skal søke adspredelse og nye indtryk, så var det vel rimelig de søkte bort fra dette livet og ind dit, hvor de oprindelig hører hjemme: den store frie natur (Nansen, 1942, s. 578).
Dette citat rummer både et perspektiv, en mindre analyse og en kritisk vurdering af datidens moderne mennesker og deres livsførelse.

Ved at forestille sig et væsen uden for kloden, der kigger ned på jorden, sætter Fridtjof Nansen perspektiv på menneskenes liv. Dette væsen, der kigger på kloden udefra, kunne ligeså godt være Nansen selv. Nansen har med sine ekspeditioner ud i verden fået det norske hverdagsliv på distance. Derude har en stor verden åbnet sig for ham. Men som det kommer til udtryk i talen, sætter denne tale også perspektiv på livet hjemme, som han anskuer med nye øjne.

Ved at være på ekspedition skabes en kontrast og et perspektiv, ikke kun til den kultur der undersøges, men også til den kultur vi kommer fra.

På en ekspedition tager man af sted alene eller i en lille forskningsgruppe, færdes i landskabet, har et fagligt fokus og lever det enkle liv. Ved at leve det enkle liv skabes kontrasten til hverdagen og hverdagens bekvemmeligheder. Ekspeditionslivet er væsentlig forskelligt fra hverdagslivet. Vi befinder os i tæt kontakt med naturen, vi forflytter os og ser verden fra nye perspektiver og er $\mathrm{i}$ en anden tidslomme og rytme.

\section{Om at vaere fremmed}

På ekspeditionen handler det ikke kun om at komme tæt på den kultur, som man vil undersøge. Det handler også om at gøre sig fremmed i forhold til den selvsamme. I etnologien anvender man begrebet "estrangement". Estrangement er: "a cognitive state where the natural attitude "thinking as usual" is suspended and the ethnographer is forced to see sets of activities in (supposedly) "social facts" (Gobo, 2008, s. 148-149).

Det er vigtigt at se den kultur, man undersøger fra forskellige perspektiver. Forskeren påtager sig det hverv, som Schultz kalder "the atti- 
tude of the stranger" (Schuetz, 1944, s. 507). Fordelen ved at være fremmed er, at det som de hjemmevante tager for givet, ser vi med andre øjne. Forskeren skal være opmærksom på de detaljer, der for andre er banale eller irrelevante. Hensigten er at få adgang til de underliggende strukturer i kulturen.

Det er imidlertid vanskeligt at suspendere den naturlige attitude og opnå "stranger"-attituden. Det er her ekspeditionen (og i vores tilfælde friluftslivet) kan komme os til hjælp. Da vi kom roende ind mod campingpladsen i Bøjden efter at have overnattet i Damsbo skov, følte vi vitterligt, at vi var fremmede, der kom til ukendt land. Og dette på trods af at afstanden til mit eget hjem var under 20 kilometer. Igennem det at tage på tur opstår muligheden for at skabe distance til både den kultur forskeren kommer fra, og den som forskeren ønsker at undersøge, og herved etableres muligheden for at se verden med "andre" øjne.

\section{KULTURMØDET OG OM AT KOMME TAET PÅ}

Det handler imidlertid ikke kun om at gøre sig fremmed. Ekspeditionen som metode bygger på en erkendelse af, at vigtig kundskab knytter sig til situationen og stedet. Det kulturmøde, der etableres igennem udøvelse af friluftsliv, er derfor helt centralt. Det handler om at komme tæt på kulturen, opleve nærhed, intimitet, detaljerigdom og nuancer (Tordsson, 2010).

I forbindelse med mit projekt var jeg interesseret $\mathrm{i}$ at vide, hvilket forhold landmanden Preben fra Rørmosegård på Helnæs havde til naturen, og hvordan han brugte den i praksis. Jeg havde forberedt nogle spørgsmål, som jeg stillede ved kaffebordet hos Preben og Jette. Men det skulle vise sig, at mine spørgsmål var for overfladiske - jeg havde ikke nok indsigt til at stille dybe spørgsmål. Det var først, da vi kom ud i terrænet og gik forbi rørmosen og kom ned til havet, at der i mere end en forstand åbnede sig et større univers. Her ude kunne Preben fortælle, så jeg kunne forstå og fortællingerne blev flere, konkrete, nærværende og større. Med rørmosen i ryggen og Helnæsbugten foran os, spurgte jeg ind til jagten, og Preben fortalte, at han førhen kunne skyde en del troldænder og bjergænder ud for Rørmosegård i Nørrefjorden, men at fuglene nu ikke så ofte trækker der. Så nu ror han derimod i jagtsæsonen ud til området mellem Helnæs og Illum ø for at skyde edderfugle. Han viste mig, hvor og hvordan lokkeænderne skulle placeres, og hvordan vejr og vindforhold spiller ind. "Det er en charme at få lagt lokkecenderne rigtig ud, at se om man kan lokke de levende cender til eller ej", fortalte Preben. Han viste, hvordan han gjorde, og så gik vi ned til fjorden, hvor han havde fået gravet en sø. Søen er helt ny, og han har fået tilladelse til at grave den med formål at trække noget vildt til. Han pegede ud over vandet mod Tjørnhoved - "derude ligger en grund Rønnen”, fortalte han. Her mødtes man førhen ude på isen - slog hul i den og stangede ål. Siden vandrede vi rundt $\mathrm{i}$ bakkerne, og jeg så vildtageren. Igennem denne vandring i landskabet erhvervede jeg nye kundskaber om friluftsliv, kultur og natur. Jeg havde ikke de fjerneste anelser om det, Preben viste og fortalte mig, da vi sad inde ved kaffebordet. Derfor kunne jeg ikke spørge ind til det, men igennem at færdes i landskabet og lytte til Preben fik jeg ny indsigt.

Ekspeditionen som metode er et direkte møde med den konkrete verden. Der er ingen abstrakte definitioner, der skaber et filter og begrænser vores forskningsfelt. Tværtimod mødes forskeren eller forskerne af direkte indtryk. Der er farver, stemninger og æstetiske kvaliteter. 
RAMMER FOR EKSPEDITIONEN OG KULTURMøDET

En ekspedition bygger på nogle grundlæggende rammer, der også er forudsætningen for at etablere et kulturmøde. Ekspeditionsudøveren eller ekspeditionsholdet skal være af sted i længere tid i kultur- eller naturlandskabet. Han, hun eller holdet lever afsondret fra hverdagslivet (f. eks. igennem at leve det enkle friluftsliv), og ekspeditionen er som regel i bevægelse, hvilket i praksis betyder, at det videnskabelige perspektiv flyttes.

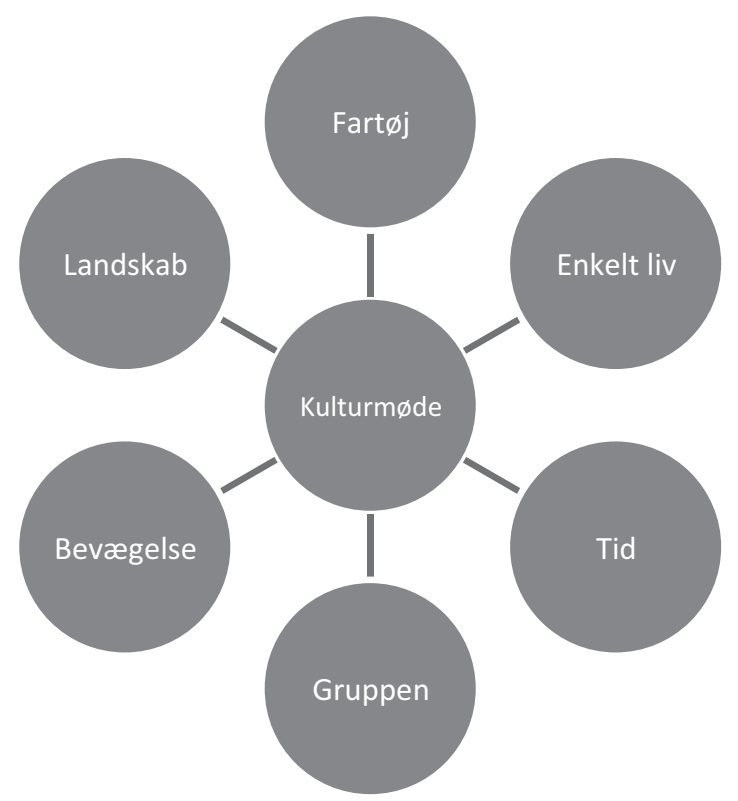

Model 2: Rammer for kulturmødet

\section{Forskningsgruppen}

Det har en stor betydning, at man er flere på en ekspedition. Forskningsgruppen planlægger ekspeditionen, sætter mål, vælger vej og lytter til hinandens ønsker i fællesskab. Undervejs gør den observationer som nedfældes. Der tilegnes viden i fællesskab og erfaringer deles. Det er flere øjne, der observerer, og derved ser ekspeditionsholdet flere ting. Men ekspeditionsholdet ser også de samme ting, som imidlertid kan opfattes forskelligt. På en ekspedition diskuteres der ofte, hvad der bliver iagttaget og hørt, og der udveksles på den baggrund erfaringer, betragtninger, fortolkninger og synspunkter. Virkeligheden belyses derfor fra forskellige perspektiver, der reflekteres, og der finder gensidig læring sted.

\section{Tid}

Inden for vejledningspædagogikken er det af stor betydning at være afsted over længere tid (Ydegaard, 2005). Denne betragtning knyttet til vejledning i friluftsliv kan overføres til ekspeditionen som metode. Såfremt kulturmødet skal have dybde, er det vigtigt, at ekspeditionsholdet er af sted i længere tid, og at ekspeditionen foregår i landskabet. Ved at være længe af sted skabes nye rammer og nye perspektiver for indlevelse. Det kræver tid at omstille sig, og det kræver tid at indleve sig i en given kultur. En ekspedition er ligeledes kendetegnet ved, at der både er rammer og tid til refleksion og erkendelse. Der skal også være tid til at opdage, forfølge spontane mål, møde nye mennesker og forfølge nye ideer. Derfor er den ikke skemalagte tid og omstillingstid vigtig i ekspeditionen som metode.

\section{Fartøjet og bevægelsen}

Jeg benyttede både smakkejollen, kanoen, kajakken, cyklen og apostlenes heste i forbindelse med mit projekt. Det fartøj, man benytter på en ekspedition, har flere funktioner. Bevægelse er et vigtigt nøgleord i den forskningsproces, der har friluftslivet som ramme. Når vi er på ekspedition, flytter vi os. Vi bevæger os fra sted til sted. Forskningsobjektet, hvad enten det er bør- 
nene, campingpladsen eller fiskelejet, der er i fokus, forandrer sig og kan betragtes forskelligt alt afhængig af, hvor vi befinder os. Det at flytte sig, bevæge sig af sted igennem vandet, overnatte på forskellige pladser, er også at ændre perspektiv - det er at se virkeligheden fra nye vinkler. På den måde kan friluftslivet og bevægelsen være med til at nuancere vores opfattelser.

På mine ture oplevede jeg, at det fartøj, der fungerede bedst til at komme i kontakt med folk, var smakkejollen. Smakkejollen har, ligesom i øvrigt kanoen og kajakken, den fordel, at den kan gå til land næsten overalt. Dernæst er smakkejollen hjemmehørende i Helnæsbugten og det Sydfynske øhav. Når jeg gik i land, oplevede jeg en særlig venlighed. Folk kom mig i møde og ville som regel gerne snakke, netop fordi jeg kom sejlende i et lokalt fartøj. Fartøjet fungerede med andre ord som mægler og hjalp til med at etablere dybe samtaler. Hvad enten jeg lagde til hos fritidsfiskerne eller på marinaen, eller på campingpladsen, oplevede jeg, at det ikke var noget problem at komme i snak med folk.

Desuden er smakkejollen med til at etablere endnu et perspektiv. I gennem det at sejle i et kulturfartøj, der har eksisteret i Helnæsbugten i mange hundrede år, opstod der både hos de grupper jeg havde med på tur og hos mig selv en historisk indlevelse i smakkekulturen, som konstruktivt kunne benyttes i kulturmødet og kulturanalysen (Haahr, 2005).

\section{ERKENDELSE PÅ FLERE NIVEAUER}

Ekspeditionen og kulturmødet danner rammer om det, der kan kaldes den situerede erkendelse (Tordsson, 2006). Denne erkendelse rummer, alt afhængig af intentionen og situationen, flere former for erkendelse. Vi kan skelne mellem erfaringserkendelse, erkendelse via en mester, kundskab knyttet til handling, erkendelse på tværs $\mathrm{i}$ forskerholdet og erkendelse som følge af refleksion. De forskellige erkendelsesformer er ikke adskilt fra hinanden med vandtætte skotter. I praksis griber de ind i hinanden.

\section{Erfaringserkendelse og kundskab via kroppen}

Jeg oplevede på mine ekspeditioner, at ville jeg forstå jollesejleren, fritidsfiskeren eller kitesurferen og deres færdsel på vandet, så var det en fordel at udøve aktiviteten. Jeg oplevede, at det at bruge fartøjet var en forudsætning for, at jeg kunne indleve mig i kulturen på et dybere plan.

Såfremt vi skal forstå smakke- og træbådskulturen er det ikke nok at læse om smakkejollen. Det er heller ikke nok at betragte den på vandet. Hvis vi skal forstå smakkesejleren, smakkejollen og det landskab, vi færdes i, må vi sejle i jollen og gerne over længere tid. Derved får vi tid til, på såvel det ubevidste som det bevidste plan, at indleve os i smakkekulturen (Haahr, 2005). Det, at vi udøver aktiviteten, skaber erkendelse. Vi fokuserer alle vores sanser på fænomenet, og vi gør det over længere tid. Der er altså tale om en fænomenologisk og hermeneutisk tilgang, hvor erfaringslæren og erfaringsrefleksionen har en stor betydning.

\section{Erfaringsrefleksion}

Erfaringslæren handler ikke blot om at gøre erfaringer. For Dewey (1997) er erfaringslære ikke kun et spørgsmål om "learning by doing." Det er vigtigt, at der på baggrund af eksperimenterer og erhvervede erfaringer, også reflekteres. Dewey opererer med erfaringer i et passivt og et aktivt element. Han gør opmærksom på, at vi gør os mange erfaringer, men det er først, når vi reflekterer over vores erfaringer, når vi opererer aktivt med dem, at vi finder ud af, hvordan tingenen hænger sammen. 
Da jeg var på ekspedition med forskerteamet fra Syddansk Universitet, gik vi i Helnæsbugten i land ved Faldsled havn, hvor blandt andet lystsejlerne holder til. Her inddelte vi os i mindre grupper og på baggrund af Henning Eichbergs konfigurationsanalysemodel (Eichberg, 2001; Mindegaard, Andkjær, \& Svendsen, 2014), foretog vi en kulturanalyse af marinaen, og det liv der udspillede sig der. Vi observerede de samme ting, men gjorde forskellige iagttagelser og nedfældede forskellige optegnelser i vores logbøger. Vi diskuterede iagttagelser i de enkelte grupper, og om aftenen omkring bålet diskuterede vi og reflekterede over vores iagttagelser. Vi diskuterede det, vi havde set og oplevet i fællesskab, og på den måde blev der lagt brikker til et fælles puslespil. Disse diskussioner og denne bevidstgørelsesproces var meget værdifuld. Vi lærte af hinanden. Der var tale om vidensdeling. Diskussionerne gav mig dybere indsigt og gjorde mig i stand til at stille nye spørgsmål. Men det hjalp mig også til at stille spørgsmålstegn ved mine egne teser, da disse blev udfordret $\mathrm{i}$ gruppen. På den måde blev vigtige brikker lagt $\mathrm{i}$ bestræbelserne på at kortlægge kulturmønstre, der kunne øge indsigt i havnekulturen.

Man kan sige, at i ekspeditionen som metode foregår der en kollektiv erkendelsesproces på baggrund af fælles observation, fælles diskussion og refleksion. Den ikke tilrettelagte tid er i denne sammenhæng også vigtig. Mellqvist, Gustavsson og Gunnarsson skriver:

A true dialogue might emerge when people are invited to participate in projects that extend over time and so allow space for difficult things as well as the unexpected. (Mellqvist, Gustavsson, \& Gunnarsson, 2012, s. 218).

\section{Erkendelse via mester}

Erkendelse via mesteren er en anden erkendelsesvej. Jeg oplevede i Helnæsbugten, at for at få indgående indsigt $\mathrm{i}$ de forskellige friluftskulturer, måtte jeg også tilegne mig kompetencer, som fiskeren, kajakroeren og sejleren var i besiddelse af. Jeg blev klar over, at kun igennem at udøve friluftskulturen ville jeg være i stand til at stille de rigtige spørgsmål og dermed få indsigt. Men jeg indså også, at det ikke er nok blot at gøre sig erfaringer. Det var ikke nok at sætte sig ud i båden og se, prøve og fejle fra distancen. Jeg opdagede, at når jeg indgik i en form for mesterlærerelation, blev udbyttet langt bedre. Der var kundskabs- og kulturbærere, som var i besiddelse af den kundskab, jeg var interesseret i. Kundskabsoverførslen i en mesterlærerelation er særdeles effektiv. Det er integreret læring, hvor sprog og handling går hånd i hånd. Lærlingen imiterer, han eller hun ser, prøver og fejler under kyndig vejledning. Derfor er det ofte på en ekspedition en ambition for forskeren eller forskerholdet at indgå i en mesterlære relation til fiskeren, kitesurferne eller kajakroeren, der mestrer den givne aktivitet.

\section{EKSPEDITIONEN SOM METODE - DISKUSSION, PERSPEKTIV, FORDELE OG ULEMPER}

Ekspeditionen som metode er en måde at opleve, erfare og erkende verden på, som står i kontrast til andre måder at indhente viden på. Mange videnskabelige traditioner tager afsæt $i$ abstrakte definitioner og sætter fokus på delelementer, der herefter skal kobles til en helhed. I ekspeditionen som metode forholder det sig omvendt. Her er fokus på den konkrete verden, på helheden før delen, og der etableres et direkte møde med det, der forskes i. Ekspeditionen som metode egner sig derfor til at undersøge konkrete forhold og komplekse sammenhænge. I mit 
projekt blev den således brugt til at forstå kitesurferne, fritidsfiskerne og lystsejlerne i Helnæsbugten og deres indbyrdes relationer

Den har mange lighedstræk med etnologiske metoder. Dens særkende er imidlertid ekspeditionen, som rummer en videnskabelige rejse, etablerede rammer og forskellige perspektiver, der etableres som følge heraf, og som er forudsætningen for at skabe det frugtbare kulturmøde, der igen fører til erkendelse.

Der er imidlertid også ulemper ved metoden. For det første er den tidskrævende, og det kan være vanskeligt at indhente systematisk og repræsentativ information. Disse fejlkilder overvindes delvis ved at være længe $\mathrm{i}$ felten.

Ekspeditionen som metode er en vej til at tage på ekspedition ind i egen kultur. Den er her afprøvet igennem det at undersøge friluftskulturer, men den kan sagtens anvendes til at undersøge mange andre kulturformer. Man kan eksempelvis forestille sig et forskerhold, der i et skib tager rundt til Danmarks havne med henblik på at undersøge forskellige kulturer. Det er da også det, Erland Porsmose gør, når han med skibet Rylen er på ekspedition i det sydfynske øhav.

Ekspeditionen som metode rummer endnu et perspektiv, der ikke skal underkendes. Thor Heyerdal, Knud Rasmussen og Fritjoff Nansen fik i kraft af deres ekspeditioner videnskaben ud af elfenbenstårnet. Grunden til at vi kender til dem og deres forskning, hænger i høj grad sammen med deres eventyr. Fritjof Nansen blev forbillede og rollemodel for mange nordmænd, og Nansens bedrifter fik stor betydning for den norske friluftstradition og det nordiske friluftsliv (Breivik, 1991). Tordsson skriver:

Friluftslivets stærke position i Norge har historiske og idehistoriske årsager. I udviklin- gen af det moderne Norge er friluftslivet således blevet tildelt en rolle i landets sociale projekter. Mens man i andre lande aktivt må begrunde og legitimere friluftslivet, er det i Norge nærmest en fælles opfattelse at friluftslivet er godt for alt og aldrig kan skade (Tordsson B., 2005, s. 11).

Fritjoff Nansen kan i høj grad tage æren for denne udvikling. Nansens ekspeditioner i kombination med hans tanker om det enkle liv i naturen, betydning af at være selvhjulpen og klare sig selv og respekten for naturen (Nansen, 1942) har inspireret mange mennesker til at udøve friluftsliv.

Ovenstående er i denne sammenhæng interessant, fordi afsættet for at udvikle ekspeditionen som metode netop er at undersøge muligheder og begrænsninger for friluftsliv. Igennem det at tage på ekspeditioner skaber Nansen opmærksomhed, interesse og lyst til at udøve friluftsliv.

Ekspeditionen som metode er en alsidig forskningsmetode, hvor der tilegnes viden med krop, sanser, tanker og følelser integreret. Ud fra ekspeditionen og primære oplevelser er det intentionen at skabe en sammenhængende indsigt, erkendelse og forståelse. Det er således en induktiv forskningsvej.

\section{REFERENCER}

Breivik, G. (1991). Debatten om friluftslivets grundlag. Tidsskrift for idroet (3).

Dewey, J. (1997). Erfarenthet och tänkande. I J. Dewey, Demokrati och utbilding. Göteborg: Daidalos AB.

Eichberg, H. (2001). Thinking contradictions. Towards a methodology of configurational analysis, or: How to reconstruct the societal significa- 
tion of movement culture and sport. I K. Dietrich, How Societies Create Movement Culture and Sport. (s. 10-23 (14 sider)). University of Copenhagen:IfI.

For-Ut. (1979). Krav til vegledere i friluftsliv. Mestre fjellet (29).

Gobo, G. (2008). Doing Ethnography. Bologna: SAGE Publications .

Gyldendal. (2015). Ekspedition. Hentede 3. september 2015 fra Den store danske: http://www. denstoredanske.dk/Sprog,_religion_og_filosofi/ Sprog/Fremmedord/e-ek/ekspedition

Holbech, J. (1841). Kaptajn Thomas Sødrings dagbog. København.

Haahr, J. (2005). Friluftslivet og den levende kulturformidling. I S. Andkjær (Red.), Friluftsliv under forandring (s. 117-133). Gylling: Forlaget Bavnebanke.

Mellqvist, H., Gustavsson, R., \& Gunnarsson, A. (2012). Using the Connoisseur Method during the introductory phase of landscape Planing and Management. Urban Forestry \& Urbaning Greening.

Mindegaard, P., Andkjær, S., \& Svendsen, A. M. (Red.). (2014). Bevaegelser og kropskulturelle mønstre. Odense: Syddansk Universitetsforlag.

Nansen, F. (juni 1942). Friluftsliv (1921). I A. Winsnes (Red.), Nansens Røst. Artikler og taler av Fridtjof Nansen 1908-1930 (s. 576-580). Nationaltrykkeriet: Jacob Dybwads Forlag.
Pedersen, J. F. (2011). Gensyn med de danskes øer I-III. Kerteminde.

Polanyi, M. (2009). The Tacit Dimension. University of Chicago Press.

Schuetz, A. (1944). The stranger: An essay in social psychology. American Journal of Sociology, s. 499-507.

Sookermany, A., \& Eriksen, J. (2007). Veglederen - et festskrift til Nils Faarlund. Oslo: GAN Aschehoug.

Telemark Distrikthøgskole. (1991). Fagplan for valgretning/årsstudium friluftsliv1991-92. Вø i Telemark: Telemark Distrikthøgskole.

Tellnes, A. (1994). Friluftsliv som metode til at ændre holdning og livsstil. I L. Emmelin (Red.), Nordisk seminar om friluftslivsforskning. Nordplan .

Tordsson, B. (2005). Hvad er frilufsliv godt for? - Værdier i og legitimering af friluftsliv i historisk perspektiv. I S. Andkjær (Red.), Friluftsliv under forandring - en antologi om fremtidens friluftsliv (s. 11-32). Gylling: Forlaget Bavnebanke.

Tordsson, B. (2006). Perspektiv på friluftslivets padagogik. Haderslev: CVU Sønderjylland.

Tordsson, B. (2010). Friluftsliv, kultur og samfunn. Oslo: Høyskoleforlaget.

Ydegaard, T. (2005). Fremtidens vejlederbegreb. I Friluftsliv under forandring. Gylling: Forlaget Bavnebanke. 